\title{
Signaling Hypothesis and Size Anomaly in Indian Stock Market
}

\author{
Nagendra Marisetty ${ }^{1}$, \& Pardhasaradhi Madasu ${ }^{2}$ \\ ${ }^{1}$ Faculty, Reva Business School, Reva University, Bangalore, Karnataka, India \\ ${ }^{2}$ Associate Professor (Finance Area), Siva Sivani Institute of Management (SSIM), Secunderabad, India \\ Correspondence: Nagendra Marisetty, Faculty, Reva Business School, Reva University, Bangalore, India. \\ E-mail: nagendra.marisetty@gmail.com
}

Received: July 26, 2021

doi:10.5539/ibr.v14n9p94

\author{
Accepted: August 11, 2021 \\ Online Published: August 17, 2021 \\ URL: https://doi.org/10.5539/ibr.v14n9p94
}

\begin{abstract}
The dividend signaling hypothesis means that dividend change announcements send signals to the market about its prospects. Market capitalization anomaly or size effect means small-cap stocks variances and returns are different than the large-cap stocks. The sample was tested for dividend change announcement, and the sample was divided into large, medium, and small sample sizes based on the market capitalization of the stocks to test the size effect. Event methodology market model used to calculate the abnormal returns on the dividend announcement day. We found that dividends send signals to the market, and the market reacts positively to the dividend change announcements on event day (Aharony and Swary 1980, Litzenberger and Ramaswamy 1982, Dhillon and Johnson 1994, Below and Johnson 1996), but results may vary with the size of the company. Small-cap companies' variances are higher than the large-cap and mid-cap companies, and also small-cap variances are not equal to other variances results similar to Wong (1989), Bandara and Samarakoon (2002), Sehgal and Tripathi (2006), and Switzer (2010). Finally, we concluded that the dividend signaling hypothesis and market capitalization or size effect anomaly exist in the Indian stock market
\end{abstract}

Keywords: cash dividend, event methodology, market capitalization effect, signaling hypothesis, S\&P BSE 500 Index

\section{JEL Classification: G32, G35}

\section{Introduction}

The popular assumption of the signaling hypothesis is that dividend change announcement is directly related to the company's future earnings. Miller and Modigliani (1961) developed the irrelevance dividend theory, which said that the company's value is independent of its dividend policy. Bhattacharya (1979), Miller and Rock (1985), and others proposed signaling theories; managers use the dividend policies as the signal to communicate their company's future to other stakeholders or outsiders of the company in the world of asymmetric information. So, a dividend increase signal is a change in a company's performance positively, and a dividend decrease signal is a change in a company's performance negatively. Accordingly, a Dividend increase follows the change in the company's returns and growth positively, and a dividend decrease follows the change in the company's returns and growth negatively. A positive association should be there between the dividend change announcement and the company's stock price.

Researchers worldwide carried many empirical tests on the signaling hypothesis, i.e., dividend change announcements and stock market returns. Most of the researchers found that dividend change announcement has a positive impact on stock market return. Pettit (1972) found that dividend change announcement strongly impacts market returns and sends strong signals to the market. Related results are found by various researchers in the USA market, such as Aharony and Swary (1980), Litzenberger and Ramaswamy (1982), Kane, Lee and Marcus (1984), Fehrs, Gary and David (1988), Dhillon and Johnson (1994), Below and Johnson (1996), Elfakahani (1998), Bessler and Nohel (1999), Wang (2005), and Douglas and Frank (2013). Asquith and Mullins (1983) support the subsequent increase of dividend may result in a more positive impact on shareholders' wealth than the dividend initiation. Healy and Palepu (1988) strongly found that dividend initiation has a positive impact and dividend omission has a negative impact on the firm's earnings.

In the European markets also, researchers found significant support on dividend change announcement influence on stock market returns and convey future earnings of the company, such as Travlos, Trigeorgis, and Vafaes 
(2001) examined the Cyprus stock market, Gurgul, Madjosz, and Mestel (2003) studied the Austrian stock market, Brio (2004) investigated the Spain stock market, Gurugul and Mestel (2006) analyzed the Germany stock market, Sponholtz (2005) studied the Denmark stock market, Dasilas (2007) examined the Greece stock market Vieira and Raposo (2007) studied the three European countries, United Kingdom, France, and Portuguese, Perepeczo (2013) found in the Poland stock market, and Berdnikova and Rogova (2014) studied the Russian stock market. Mollah (2007) supports that dividend initiation positively impacts the stock price returns. Athari (2020), proved that business risk has significantly negative impact on dividend payouts.

Authors found the same result, i.e., cash dividend changes send the signal to the share market even in Asian countries. Chen, Nieh, Da Chen, and Tang (2009) found in China, Jais, Karim, Funaoka, and Abidin (2009) studied in the Malaysian stock market, Moemen, Nasani, Shamsuddin, Abdelhameed, Muneer, and Nabi (2014) in Malaysia and the Saudi Arabia stock markets, and Asadi and Zendehdel (2014) in the Iran stock market. In India, Bapat (2005), Gupta, Dogra, Vashisht, and Ghai (2012), and Marisetty and Pasha (2017) found the stock prices reacted positively to the dividend change announcements and supported the signaling hypothesis in the Indian stock market. Lukose and Rao (2004) endorsed the dividend initiation/omission is more impact on stock prices than dividend increase/decrease changes in the Indian stock market. Many researchers worldwide empirically proved that dividend change announcements positively impact share price and send signals about the company's future earnings. But some researchers contradicted the signaling hypothesis and proved that dividend change announcements did not positively affect the share market. In the USA, Lang and Litzenberger (1989), Benartzi, Michaely, and Thaler (1997), and Blau, Fuller, and Ness (2009) proved that dividend change announcement does not send any signal to the stock market. In the other markets, Conroy, Eades, and Harris (2000) in the Japanese market, Chen, Firth, and Gao (2002) in the China market, Goergen, Renneboog, and Silva (2003) in the Germany market, and Sharma and Pandey (2014) in Indian market shown evidence for dividend changes not send any signals to the stock market.

The widespread assumption is there in the market, i.e., small-cap companies are risky and perform better than large-cap companies. Wong (1989) confirmed that small-cap returns are higher than large caps. Bandara and Samarakoon (2002) investigate the dividend announcement information content impact, dividend announcements by firm size effect, and dividend growth impact on stock prices in the Sri Lankan market. Small companies reacted strongly to dividend announcement information content and better dividend growth announcements. Sehgal and Tripathi (2006) studied the Indian stock market and confirmed that small-cap firms are statistically different than large-cap firms. Switzer (2010) proved that small-cap performance was positive compared to large-cap stocks in the USA and Canadian stock markets after 2001. Most of the authors used the event methodology market model to find the abnormal returns of the stocks around the dividend change announcements, such as Bessler and Nohel (1999), Amihud and Li (2005), Chen, Nieh, Da Chen, and Tang (2009), Jais, Karim, Funaoka, and Abidin (2009), Gunalp, Kadioglu, and Kilic (2011), Gupta, Dogra, Vashisht, and Ghai (2012), Chavali and Nusratunnisa (2013), Berdnikova and Rogova (2014), and Ngoc and Cuong (2016). Boehme (2001), Hussainey, MGBAME, and MGBAME (2011), Liu (2012), and Athari (2013), Marisetty and Babu (2018) used the regression models to find the abnormal returns around events.

This study carried cash dividends that send any signal to the stock market, and these signals change due to size effect or market capitalization in the Indian stock market. This article is organized into five sections; section 1 discusses the introduction and existing literature on dividend change announcement, signaling hypothesis, and size effect. Section 2 presents the research methodology of the study. In section 3 analyze the data empirically, section 4 presents the conclusion of the research and follows the section 5 limitations.

\section{Research Methodology}

\subsection{Objectives}

In the first objective, we will find the dividend change announcement impact the share price in the same direction in the Indian stock market. The second objective is to know the dividend change announcement's impact on share price varies with the company's size. The third objective is to determine the small companies' risk and returns are higher than large caps on the dividend announcement day.

\subsection{Hypothesis}

In the first hypothesis, we will study the relationship between stock prices and cash dividend change announcements in India. To understand that, we formulate an alternative hypothesis as follows.

$\mathrm{H} 1 \mathrm{a}=$ Cash dividend change announcements significantly impact stock prices in the Indian stock market. 
In the second hypothesis, we investigate the cash dividend change announcement impact on stocks varies with the company's size. To find that, we develop the alternative hypothesis as follows.

$\mathrm{H} 2 \mathrm{a}=$ Cash dividend change announcements' impact on stock prices varies with the size of the company.

In the third hypothesis, we analyze small-cap companies' variance with a large-cap and mid-cap company on dividend announcement day. To know that, we formulate the alternative hypothesis as follows.

H3a: $\sigma \mathrm{s} 2 \neq \sigma \mathrm{l} 2 \neq \sigma \mathrm{m} 2$ : Small-cap companies' variance is not equal to large-cap and mid-cap on the dividend announcement day.

\subsection{Data Collection}

This article is the continuation of our article titled 'Corporate Announcements and Market Efficiency: A Case on Indian Capital Market', published in International Journal of Business and Management (IJBM). Following data collection part adopted from that article. This study's period is from 2007 - 19 (13 years period), which is the period that witnessed significant fluctuations in the Indian stock market. During this period, stocks went from high level to low level and low level to high level two to three times. Many stock exchanges are operating in India, but only two, namely the Bombay Stock Exchange (BSE) and National Stock Exchange, are the major exchanges that operate at the national level. BSE is one of the oldest stock exchanges, and a greater number of companies are listed on the exchange in India. BSE has been selected for the representation of the Indian Stock Market for the selection of corporate actions and identification of the companies. Stock price information collected from the BSE website, corporate action information collets from moneycontrol.com, capitalmarkets.com, and data cross-check with the BSE website.

Sample events selected from S\&P BSE 500 companies only because S\&P BSE 500 is a broader index and index constitutes $90 \%$ above the capitalization of the total market capitalization. BSE Large-cap, BSE Mid-cap, and BSE small-cap indexes were used to segregate the sample into market capitalization wise. BSE stock exchange regularly reconstitutes the indexes based on market capitalization wise of the companies, so it makes it challenging to select the sample for the study. Hence market capitalization base has taken companies that are there in January 2020 BSE indexes list only. Two assumptions were assumed for the selected sample for dividend action. First, the minimum investor preference of dividends is 10 percent. The second one is that the announcement of dividends is compulsory every year because it gives to measure the dividend change announcements from the same company sample.

In the first step, total dividend actions are considered, which are announced during the research period. In the second step, in a year, if any company announced dividends more than one time, then taken only one dividend (preference given final dividend if not highest percentage interim dividend picked) and excluded other dividend actions for study. In the third step, the sample only included $10 \%$ and above dividend actions. In step four, the identification of companies that have paid dividends regularly every year throughout the research period. In step five, only S\&P BSE 500 index companies were selected from step four companies. In steps 6, 7, and 8, large-cap, mid-cap, and small-cap companies were selected from S \& P BSE 500 companies chosen from step five.

Table 1. Break-up of the cash dividend actions based on different market capitalization wise

\begin{tabular}{clcccc}
\hline S. No & Type of Capitalization & Pure Cash Dividend & Contaminate with other Events & Price info missing* & Total \\
\hline 1 & Large-cap & 627 & 45 & 36 & 708 \\
2 & Mid-cap & 552 & 36 & 48 & 636 \\
3 & Small-cap & 1074 & 42 & 348 & 1464 \\
4 & Full Sample & 2253 & 123 & 432 & 2808 \\
\hline
\end{tabular}

Note: * 3 large-cap, 4 mid-cap and 29 small-cap companies are not traded some days during research a period Source: Author's Calculations

The total sample size selected from the selection process is 2808 dividend announcements, in that 2253 pure cash dividend announcements, 123 cash dividends contaminate with other corporate announcements, and 432 price missing announcements. Some samples were removed from the analysis because those sample's price information is missing for some trading days during the event window and estimation window. The final sample for analysis is as follows, 2253 pure dividend actions (627 large-caps, 552 mid-caps, and 1074 small-caps). 
Table 2. Break-up of the dividend change announcements based on different market capitalization wise

\begin{tabular}{llllll}
\hline \multirow{2}{*}{ S. No } & Type of Capitalization & $\begin{array}{l}\text { Dividend } \\
\text { Increase }\end{array}$ & $\begin{array}{l}\text { Dividend } \\
\text { Decreases }\end{array}$ & $\begin{array}{l}\text { Dividend } \\
\text { Change }\end{array}$ & No \\
\hline 1 & Large-cap & 382 & 126 & 119 & 627 \\
2 & Mid-cap & 300 & 102 & 150 & 552 \\
3 & Small-cap & 523 & 178 & 373 & 1074 \\
4 & Full Sample & 1205 & 406 & 642 & 2253 \\
\hline
\end{tabular}

Source: Author's Calculations by using dividend information from moneycontrol.com

Pure cash dividend actions again split to dividend increases, decreases, and no change based on dividend change announcements compare to present year dividend with previous year dividend. The dividend increases sample is much higher than the other two classifications, i.e., dividend decreases and no change dividend.

\subsection{Event Window Selection}

India being a developing country with an evolving capital market, is characterized by volatility in a short period. The transparency of the corporate world is questionable, and there appears to be large-scale insider trading before the action of any event. Therefore, the researcher has chosen 61 days as the event window for the study on the impact of corporate actions on the stock market. This 61-day event window, which is defined as 0-days (the date on which the event is publicly announced) and -30 to +30 days (the date 30 days previous from the event date and 30 days post event dates) for the study.

This study is associated with the stock price behavior surrounding the action date and therefore labeled as an event study. The methodology of an event study is associated with the Efficient Market Hypothesis developed by E. F. Fama (1970) to understand the adjustment of stock prices to new information. The methodology is commonly referred to as the Fama Fisher Jensen and Ross (FFJR 1969) methodology of an event study. The steps followed to study the events are as follows;

Step1: Identify the events to be studied and pinpoint the date $(i=0)$ on which the events are announced.

Step2: Decide on the event window (ensure that during this period, no other important event has been announced). The event window corporate action as $i=0$ (Event date) and a period of -30 days previous to the event date and +30 days after the event date, which is shown below with the help of the graph.

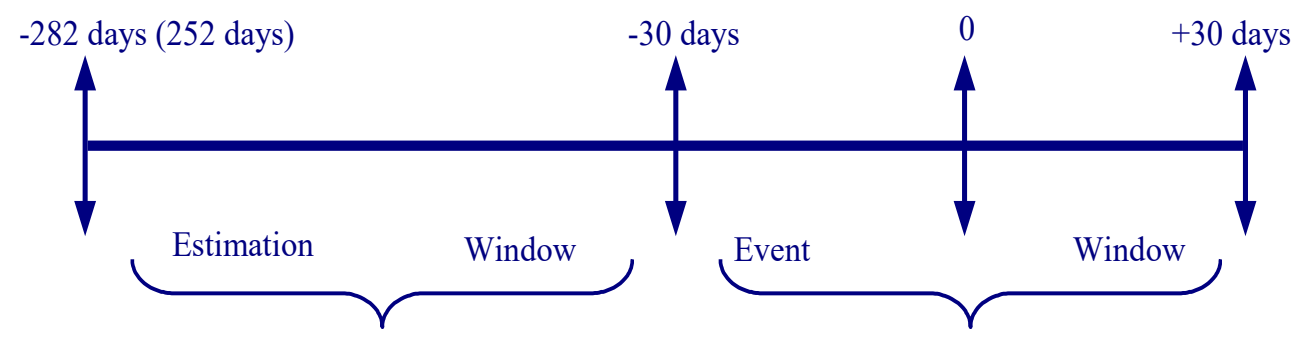

In this figure, $\mathrm{i}=0$ is shown as the event action date, and the respective effect of this action on share prices is calculated for the period of -30 days to +30 days to know if there is any impact of such action and for how many days it persists. The estimation window will be -282 days to -30 days of the event day window to regress the stock and index. The market model is used to calculate the average abnormal returns during the event window period.

\subsection{Market Model as Follows}

The simple regression model is used to calculate the stocks' expected returns during the event window in the market model. Marisetty et al. (2020) proved that the market model is slightly superior to other expected return models.

$$
\begin{aligned}
& \mathrm{ER}_{\mathrm{i}}=\alpha_{\mathrm{s}}+\beta_{\mathrm{s}} \mathrm{R}_{\mathrm{mi}}+\varepsilon_{\mathrm{s}} \\
& \mathrm{ER}_{\mathrm{i}}=\text { Expected Return of stock on the day } \mathrm{i} \text { in the event window } \\
& \alpha_{\mathrm{s}}=\text { Alpha coefficient of stock with the Index during the estimation window } \\
& \beta \mathrm{s}=\text { Beta of the stock with the Index during the estimation window } \\
& \mathrm{R}_{\mathrm{mi}}=\text { Return of the Index in the event window on the day I, } \varepsilon_{\mathrm{s}}=\text { Error term }
\end{aligned}
$$


Abnormal returns calculated as follows

$$
\begin{aligned}
A R_{i}=R_{i}-E R_{i} & \\
& A R_{i}=\text { Abnormal return of the stock on the day } i \text { during the event window } \\
& R_{i}=\text { Actual return of the stock on the day } i \text { during the event window }
\end{aligned}
$$

Average Abnormal Returns calculated as follows

$$
\mathrm{AAR}_{\mathrm{i}}=\frac{\sum_{\mathrm{s}=1}^{\mathrm{n}} \mathrm{ARts}}{\mathrm{n}}
$$

$\mathrm{AAR}_{\mathrm{i}}=$ Average abnormal return of the stocks on day $\mathrm{i}$ in the event window

$\mathrm{AR}_{\mathrm{ts}}=$ Abnormal returns of the stock on the day $\mathrm{i}$ in the event window

$\mathrm{n}=$ Total number of stocks in the study

Cumulative Abnormal Returns in the event window are calculated as follows

$$
\mathrm{CAAR}_{\mathrm{i}}=\mathrm{AAR}_{\mathrm{i}}+\mathrm{CAAR}_{\mathrm{i}-1}
$$

$\mathrm{CAAR}_{\mathrm{i}}=$ Cumulative average abnormal return on the day $i$ in the event window

$\mathrm{CAAR}_{\mathrm{i}-1}=$ Cumulative average abnormal return on the day $\mathrm{i}-1$

$\mathrm{t}$ test used to determine the significance of the average abnormal returns

$$
\mathrm{t} \text { test }=\frac{\text { AARi }}{\sigma(\mathrm{ARi})}
$$

$$
\begin{aligned}
& \mathrm{AAR}_{\mathrm{i}}=\text { Average abnormal return of the stocks on day } \mathrm{i} \text { in the event window } \\
& \sigma\left(\mathrm{AR}_{\mathrm{i}}\right)=\text { Standard error of abnormal returns of stocks on the day } \mathrm{i} \text { event }
\end{aligned}
$$

Standard error is calculated $\sigma\left(\mathrm{AR}_{\mathrm{i}}\right)=\frac{\sigma \mathrm{i}}{\sqrt{\mathrm{n}}}$

$$
\sigma_{\mathrm{i}}=\text { Standard deviation of stocks abnormal return on the day } \mathrm{i} \text { in event }
$$

\begin{tabular}{|c|c|c|c|c|c|c|c|c|c|}
\hline \multirow{2}{*}{ EW } & \multicolumn{3}{|c|}{ Dividend Increases $\mathrm{N}=1205$} & \multicolumn{3}{|c|}{ Dividend Decreases N = 403} & \multicolumn{3}{|c|}{ Dividend No Change $\mathrm{N}=645$} \\
\hline & AAR $(\%)$ & CAAR (\%) & t Values & AAR $(\%)$ & CAAR $(\%)$ & $\mathrm{t}$ Values & AAR $(\%)$ & CAAR (\%) & $\mathrm{t}$ Values \\
\hline-30 & 0.0462 & 0.0462 & 0.7784 & 0.1075 & 0.1075 & 0.9975 & 0.159 & 0.159 & $1.7840^{*}$ \\
\hline-29 & 0.0031 & 0.0493 & 0.0549 & -0.0406 & 0.0669 & -0.4531 & 0.0373 & 0.1963 & 0.4265 \\
\hline-28 & 0.1079 & 0.1572 & $1.7073^{*}$ & 0.0521 & 0.1191 & 0.5148 & 0.0458 & 0.2421 & 0.5582 \\
\hline-27 & 0.036 & 0.1933 & 0.5847 & 0.3974 & 0.5165 & $3.5266^{* * *}$ & -0.1827 & 0.0594 & $-2.3757^{* *}$ \\
\hline-26 & 0.0339 & 0.2272 & 0.6105 & 0.1656 & 0.6821 & 1.4938 & 0.1203 & 0.1797 & 1.3479 \\
\hline-25 & -0.0323 & 0.1948 & -0.5755 & 0.1263 & 0.8083 & 1.2382 & -0.101 & 0.0787 & -1.1997 \\
\hline-24 & 0.0035 & 0.1983 & 0.0584 & -0.0422 & 0.7661 & -0.4643 & -0.1862 & -0.1075 & $-2.0924^{* *}$ \\
\hline-23 & -0.0278 & 0.1706 & -0.4665 & 0.0019 & 0.768 & 0.0173 & 0.0896 & -0.0179 & 1.0521 \\
\hline-22 & 0.0271 & 0.1977 & 0.4653 & 0.0047 & 0.7726 & 0.0427 & 0.0963 & 0.0784 & 1.1994 \\
\hline-21 & -0.042 & 0.1557 & -0.763 & 0.0705 & 0.8432 & 0.6302 & 0.0386 & 0.1171 & 0.427 \\
\hline-20 & -0.0235 & 0.1322 & -0.4173 & 0.0494 & 0.8925 & 0.4485 & -0.025 & 0.0921 & -0.307 \\
\hline-19 & -0.0004 & 0.1319 & -0.0066 & 0.1769 & 1.0694 & 1.5261 & 0.0568 & 0.1489 & 0.6926 \\
\hline-18 & 0.0218 & 0.1536 & 0.3798 & -0.1031 & 0.9664 & -0.9499 & 0.1381 & 0.2871 & 1.4466 \\
\hline-17 & 0.0557 & 0.2094 & 0.981 & -0.0054 & 0.9609 & -0.0479 & 0.1623 & 0.4494 & $1.7843^{*}$ \\
\hline-16 & -0.0683 & 0.141 & -1.2111 & 0.0922 & 1.0531 & 0.8393 & -0.0513 & 0.3981 & -0.6113 \\
\hline-15 & -0.0185 & 0.1225 & -0.3058 & -0.1723 & 0.8808 & $-1.7938^{*}$ & 0.0728 & 0.4708 & 0.8707 \\
\hline-14 & 0.0024 & 0.1249 & 0.045 & -0.0928 & 0.788 & -0.9395 & 0.0479 & 0.5187 & 0.4802 \\
\hline-13 & -0.0638 & 0.0611 & -1.0178 & 0.0423 & 0.8303 & 0.44 & -0.0197 & 0.499 & -0.2566 \\
\hline
\end{tabular}

\subsection{Market Capitalization or Size Effect Analysis}

Co-efficient variation is used to compare the performance of different caps average abnormal returns and their standard deviation. F test used to determine the capitalization variances are not equal to one other.

\section{Data Analysis and Interpretation}

\subsection{Full Sample Stocks}

Table 3. Full sample dividend change announcements average abnormal returns (AAR), cumulative average abnormal returns (CAAR), and AAR t values 


\begin{tabular}{|c|c|c|c|c|c|c|c|c|c|}
\hline-12 & 0.0669 & 0.128 & 1.1542 & -0.0525 & 0.7778 & -0.5032 & 0.2448 & 0.7438 & $2.6049^{* * * *}$ \\
\hline-11 & -0.0473 & 0.0807 & -0.848 & -0.0574 & 0.7203 & -0.6054 & -0.0939 & 0.6498 & -1.2205 \\
\hline-10 & -0.0181 & 0.0626 & -0.3147 & 0.1999 & 0.9202 & 1.6106 & 0.1075 & 0.7574 & 1.2965 \\
\hline-9 & 0.0051 & 0.0677 & 0.0895 & -0.0905 & 0.8297 & -0.9452 & 0.0618 & 0.8192 & 0.7557 \\
\hline-8 & 0.015 & 0.0827 & 0.2523 & 0.0454 & 0.8751 & 0.397 & -0.0021 & 0.8171 & -0.0222 \\
\hline-7 & -0.0126 & 0.0701 & -0.2111 & 0.2273 & 1.1024 & $1.9887^{* *}$ & 0.2055 & 1.0226 & $2.2162^{* * *}$ \\
\hline-6 & 0.0678 & 0.138 & 1.1668 & -0.0579 & 1.0445 & -0.5522 & 0.0251 & 1.0477 & 0.2881 \\
\hline-5 & -0.0132 & 0.1247 & -0.2354 & 0.0903 & 1.1348 & 0.7467 & 0.2001 & 1.2478 & $2.0440^{* * *}$ \\
\hline-4 & -0.0342 & 0.0906 & -0.5736 & -0.0021 & 1.1327 & -0.0197 & -0.0094 & 1.2384 & -0.0932 \\
\hline-3 & 0.0476 & 0.1382 & 0.8305 & 0.1762 & 1.3089 & $1.6781^{*}$ & 0.0398 & 1.2782 & 0.4413 \\
\hline-2 & 0.2146 & 0.3528 & $3.666^{* * * *}$ & -0.0326 & 1.2763 & -0.3074 & 0.2109 & 1.4891 & 1.5418 \\
\hline-1 & 0.2319 & 0.5847 & $3.453^{* * * *}$ & 0.0607 & 1.337 & 0.6218 & 0.136 & 1.6252 & 1.4583 \\
\hline 0 & 0.3683 & 0.9531 & $3.537^{* * * *}$ & -0.1471 & 1.1898 & -0.886 & 0.0625 & 1.6877 & 0.4835 \\
\hline 1 & 0.0849 & 1.038 & 0.8208 & -0.2319 & 0.9579 & -1.3803 & -0.2529 & 1.4348 & $-1.7459^{*}$ \\
\hline 2 & -0.0022 & 1.0358 & -0.0317 & -0.0049 & 0.953 & -0.0397 & -0.2008 & 1.234 & $-2.249^{* * *}$ \\
\hline 3 & -0.0016 & 1.0343 & -0.0246 & 0.0994 & 1.0524 & 0.8977 & 0.1277 & 1.3617 & 1.421 \\
\hline 4 & 0.0121 & 1.0464 & 0.1972 & -0.0712 & 0.9812 & -0.678 & -0.034 & 1.3277 & -0.3526 \\
\hline 5 & -0.0574 & 0.989 & -0.9186 & -0.1414 & 0.8398 & -1.0872 & 0.0674 & 1.3951 & 0.75 \\
\hline 6 & 0.0434 & 1.0324 & 0.7218 & 0.0024 & 0.8422 & 0.0223 & 0.0072 & 1.4023 & 0.0878 \\
\hline 7 & -0.0163 & 1.0161 & -0.2633 & 0.1245 & 0.9668 & 1.129 & 0.091 & 1.4933 & 1.0883 \\
\hline 8 & -0.108 & 0.9081 & $-1.9305^{*}$ & -0.0147 & 0.952 & -0.1376 & -0.1024 & 1.3909 & -1.2569 \\
\hline 9 & -0.0245 & 0.8837 & -0.4056 & -0.1315 & 0.8205 & -1.3761 & 0.0181 & 1.4089 & 0.2262 \\
\hline 10 & -0.0693 & 0.8144 & -1.1942 & -0.0104 & 0.8102 & -0.0937 & -0.0587 & 1.3502 & -0.727 \\
\hline 11 & -0.0129 & 0.8015 & -0.2254 & 0.0902 & 0.9004 & 0.7148 & -0.0359 & 1.3144 & -0.3859 \\
\hline 12 & 0.0677 & 0.8691 & 1.169 & 0.2197 & 1.1201 & $2.2147^{* *}$ & 0.1546 & 1.469 & $1.7443^{*}$ \\
\hline 13 & -0.0704 & 0.7987 & -1.2474 & 0.0803 & 1.2004 & 0.7391 & 0.124 & 1.593 & 1.1808 \\
\hline 14 & -0.0082 & 0.7905 & -0.1355 & 0.2843 & 1.4847 & $2.6252^{* * * *}$ & 0.1115 & 1.7044 & 1.1891 \\
\hline 15 & -0.0387 & 0.7518 & -0.6572 & 0.1619 & 1.6467 & 1.5399 & 0.0506 & 1.755 & 0.5901 \\
\hline 16 & -0.055 & 0.6968 & -0.9857 & -0.0721 & 1.5746 & -0.7518 & 0.0852 & 1.8402 & 0.9258 \\
\hline 17 & -0.0845 & 0.6123 & -1.432 & 0.1103 & 1.6849 & 1.0497 & 0.0506 & 1.8908 & 0.6152 \\
\hline 18 & -0.0856 & 0.5267 & -1.5169 & 0.0796 & 1.7645 & 0.7169 & -0.0478 & 1.8429 & -0.5534 \\
\hline 19 & -0.0374 & 0.4893 & -0.6176 & 0.0311 & 1.7957 & 0.3136 & 0.0371 & 1.88 & 0.3694 \\
\hline 20 & -0.1252 & 0.3641 & $-2.3603^{* * *}$ & 0.0139 & 1.8096 & 0.1259 & -0.0856 & 1.7945 & -1.0056 \\
\hline 21 & 0.0723 & 0.4364 & 1.204 & -0.1906 & 1.6189 & $-1.8270^{*}$ & -0.0937 & 1.7007 & -1.0877 \\
\hline 22 & 0.002 & 0.4384 & 0.0355 & -0.0713 & 1.5476 & -0.6149 & 0.0541 & 1.7548 & 0.602 \\
\hline 23 & 0.0118 & 0.4502 & 0.2159 & -0.0942 & 1.4534 & -0.9927 & 0.0846 & 1.8394 & 1.0619 \\
\hline 24 & -0.054 & 0.3962 & -0.9469 & 0.1158 & 1.5692 & 1.1559 & 0.0509 & 1.8903 & 0.6139 \\
\hline 25 & 0.0525 & 0.4487 & 0.9542 & 0.229 & 1.7982 & $1.8612^{*}$ & 0.2302 & 2.1205 & $2.2209^{* * *}$ \\
\hline 26 & -0.0282 & 0.4205 & -0.499 & 0.3127 & 2.1109 & $2.7026^{* * * *}$ & -0.0037 & 2.1168 & -0.0434 \\
\hline 27 & 0.0322 & 0.4528 & 0.5294 & 0.009 & 2.1199 & 0.0997 & -0.0331 & 2.0837 & -0.4154 \\
\hline 28 & -0.0009 & 0.4518 & -0.016 & 0.1457 & 2.2656 & 1.4105 & 0.0607 & 2.1445 & 0.7562 \\
\hline 29 & -0.0556 & 0.3963 & -0.9728 & 0.0344 & 2.3 & 0.3279 & -0.1565 & 1.988 & $-1.8617^{*}$ \\
\hline 30 & 0.0048 & 0.4011 & 0.0773 & 0.0188 & 2.3187 & 0.181 & 0.0265 & 2.0145 & 0.3117 \\
\hline
\end{tabular}

Note: *** significant @ 1\%,** significant @ 5\% and *significant @ 10\% level

Source: Author's calculations

It is observed from the table that full sample dividend increase announcement average abnormal returns (AAR) are positive on event day and statistically significant at 1 percent level. Abnormal returns are positive and significant at a 1 percent level on -1 and -2 days before the event day. It shows that investors are expecting positive signals from dividend increase stocks. But after event day, abnormal returns were either slightly positive or negative and not observed no significant returns in most of the days. Cumulative abnormal returns are positive throughout the window period; returns are increased till the event day. But after the sixth day of the event, returns shown a decreasing trend till the end of the window. From the table, the full sample dividend decrease announcement average abnormal returns (AAR) are negative on event day and statistically not significant. Abnormal returns are positive in most of the days before the event and significant in four days. Abnormal returns are negative after the event, but after the third day of the event, returns are positive on most of the days, and also returns are significant on some days. Cumulative abnormal returns are positive throughout the window period; returns are increased till the event day and after the event day, also returns shown an increasing trend till the end of the window.

It can be said that full sample dividend no change announcement average abnormal returns (AAR) are slightly positive on event day and statistically not significant. Abnormal returns are positive in most of the days before the event, and returns are significant in seven days. Abnormal returns are negative and significant on -1 and -2 days, two days after the event day. Abnormal returns are negative after the event, but after the third day of the event, 
returns are positive on most of the days, and also returns are significant on some days. Cumulative abnormal returns are positive in most of the days' window period; returns are increased till the event day, and after the event day also, returns shown an increasing trend till the end of the window. We can say from the above discussion that full sample dividend change announcements have impacted the same direction on stock prices in India. It means that if a company increases dividend when compared to the previous year, then market price increase accordingly, so the market is taking the positive signal from dividend increases, and shares are reacting positively on the event day. Suppose dividend decrease announcement happens when compare previous year dividend the share price also decreasing on the event day. For dividend, no change announcement means a company is not changing dividend when compared to the previous year, then share price also no change on the event day.

\subsection{Large-Caps}

Table 4. Large-cap sample dividend change announcements average abnormal returns (AAR), cumulative average abnormal returns (CAAR), and AAR t values

\begin{tabular}{|c|c|c|c|c|c|c|c|c|c|}
\hline \multirow{2}{*}{ EW } & \multicolumn{3}{|c|}{ Dividend Increases N = 382} & \multicolumn{3}{|c|}{ Dividend Decreases $\mathrm{N}=126$} & \multicolumn{3}{|c|}{ Dividend No Change $\mathrm{N}=119$} \\
\hline & $\operatorname{AAR}(\%)$ & CAAR (\%) & t Values & $\operatorname{AAR}(\%)$ & CAAR (\%) & t Values & $\operatorname{AAR}(\%)$ & CAAR (\%) & t Values \\
\hline-30 & -0.0061 & -0.0061 & -0.0727 & -0.1533 & -0.1533 & -1.033 & 0.0216 & 0.0216 & 0.1482 \\
\hline-29 & -0.0689 & -0.075 & -0.8478 & -0.0798 & -0.2331 & -0.5032 & 0.3277 & 0.3493 & $2.2126^{* *}$ \\
\hline-28 & 0.0906 & 0.0156 & 1.0202 & -0.1928 & -0.4259 & -1.1266 & 0.1791 & 0.5284 & 0.9106 \\
\hline-27 & -0.0857 & -0.0701 & -1.0194 & 0.2955 & -0.1303 & $1.7902^{*}$ & -0.1544 & 0.374 & -1.0943 \\
\hline-26 & 0.0773 & 0.0072 & 0.8926 & 0.0622 & -0.0682 & 0.349 & 0.0336 & 0.4076 & 0.1752 \\
\hline-25 & 0.1493 & 0.1565 & $1.6940^{*}$ & -0.0576 & -0.1257 & -0.3206 & -0.217 & 0.1906 & -1.5656 \\
\hline-24 & -0.0537 & 0.1028 & -0.6998 & -0.1139 & -0.2396 & -0.7619 & -0.0943 & 0.0962 & -0.5642 \\
\hline-23 & 0.0563 & 0.1591 & 0.6336 & 0.3727 & 0.1331 & $2.0796^{* *}$ & -0.1924 & -0.0962 & -1.3614 \\
\hline-22 & -0.1501 & 0.0091 & $-1.8423^{*}$ & -0.092 & 0.0411 & -0.5805 & 0.1869 & 0.0907 & 1.12 \\
\hline-21 & -0.0765 & -0.0674 & -0.9721 & -0.2329 & -0.1918 & -1.14 & -0.1586 & -0.0679 & -0.9548 \\
\hline-20 & -0.1109 & -0.1783 & -1.3537 & 0.137 & -0.0548 & 0.8033 & -0.0885 & -0.1563 & -0.5532 \\
\hline-19 & 0.0143 & -0.1641 & 0.16 & 0.0957 & 0.0409 & 0.4704 & 0.2001 & 0.0438 & 1.2004 \\
\hline-18 & -0.0688 & -0.2328 & -0.7991 & 0.1818 & 0.2227 & 1.0555 & 0.1426 & 0.1864 & 0.8388 \\
\hline-17 & -0.0088 & -0.2416 & -0.1127 & -0.0555 & 0.1672 & -0.3377 & 0.1721 & 0.3585 & 1.0362 \\
\hline-16 & 0.0991 & -0.1425 & 1.1683 & 0.0794 & 0.2465 & 0.4466 & 0.1491 & 0.5076 & 0.9236 \\
\hline-15 & -0.0908 & -0.2333 & -0.9758 & 0.0202 & 0.2668 & 0.1346 & -0.1136 & 0.394 & -0.7278 \\
\hline-14 & 0.0248 & -0.2085 & 0.3078 & 0.0628 & 0.3296 & 0.3835 & 0.1598 & 0.5538 & 1.0349 \\
\hline-13 & -0.1086 & -0.3171 & -1.2071 & 0.2253 & 0.5549 & 1.2582 & 0.0915 & 0.6453 & 0.5476 \\
\hline-12 & 0.0082 & -0.3089 & 0.0949 & 0.1235 & 0.6784 & 0.6535 & 0.2117 & 0.857 & 0.931 \\
\hline-11 & 0.0083 & -0.3005 & 0.0942 & -0.2352 & 0.4432 & -1.5232 & -0.2029 & 0.6541 & -1.2056 \\
\hline-10 & -0.0198 & -0.3203 & -0.2213 & 0.0047 & 0.4479 & 0.0282 & 0.0582 & 0.7124 & 0.3765 \\
\hline-9 & 0.0123 & -0.308 & 0.152 & -0.0885 & 0.3595 & -0.5601 & 0.0342 & 0.7466 & 0.2175 \\
\hline-8 & -0.0804 & -0.3884 & -0.8233 & 0.1936 & 0.5531 & 0.8682 & -0.2773 & 0.4693 & $-1.7670^{*}$ \\
\hline-7 & -0.0049 & -0.3933 & -0.0598 & 0.1485 & 0.7016 & 0.9417 & 0.3276 & 0.7969 & 1.5929 \\
\hline-6 & 0.1243 & -0.269 & 1.1943 & -0.0009 & 0.7007 & -0.0058 & -0.1198 & 0.6771 & -0.7415 \\
\hline-5 & -0.094 & -0.363 & -0.997 & -0.092 & 0.6087 & -0.5163 & 0.1224 & 0.7995 & 0.7996 \\
\hline-4 & -0.1734 & -0.5364 & $-2.0226^{* *}$ & -0.2583 & 0.3504 & -1.4631 & -0.1524 & 0.6471 & -0.8991 \\
\hline-3 & 0.117 & -0.4194 & 1.3476 & 0.0127 & 0.3631 & 0.0741 & 0.0956 & 0.7427 & 0.4892 \\
\hline-2 & 0.1719 & -0.2475 & $1.9188^{*}$ & -0.0142 & 0.3489 & -0.0743 & -0.1371 & 0.6055 & -0.7234 \\
\hline-1 & 0.089 & -0.1586 & 0.8581 & 0.3473 & 0.6962 & $2.2882^{* *}$ & 0.1179 & 0.7235 & 0.6573 \\
\hline 0 & -0.0533 & -0.2119 & -0.3694 & -0.1347 & 0.5614 & -0.4278 & 0.1943 & 0.9178 & 0.7856 \\
\hline 1 & 0.1656 & -0.0463 & 0.9656 & -0.1557 & 0.4057 & -0.5344 & -0.1636 & 0.7542 & -0.4671 \\
\hline 2 & 0.0148 & -0.0315 & 0.1409 & 0.204 & 0.6098 & 1.0948 & -0.0826 & 0.6716 & -0.4522 \\
\hline 3 & -0.0461 & -0.0776 & -0.5111 & 0.0907 & 0.7005 & 0.489 & 0.0297 & 0.7014 & 0.1692 \\
\hline 4 & 0.0406 & -0.037 & 0.4443 & 0.0461 & 0.7466 & 0.3238 & -0.0851 & 0.6163 & -0.3378 \\
\hline 5 & 0.0762 & 0.0392 & 0.9148 & -0.2166 & 0.53 & -1.4429 & -0.1927 & 0.4236 & -1.0136 \\
\hline 6 & 0.1098 & 0.149 & 1.183 & -0.043 & 0.487 & -0.2414 & -0.1098 & 0.3138 & -0.6793 \\
\hline 7 & -0.142 & 0.007 & -1.5821 & 0.1194 & 0.6064 & 0.6199 & 0.0502 & 0.364 & 0.3385 \\
\hline 8 & 0.0016 & 0.0086 & 0.0197 & 0.2038 & 0.8102 & 1.3558 & -0.2164 & 0.1476 & -1.3734 \\
\hline 9 & 0.0583 & 0.0669 & 0.5992 & -0.3445 & 0.4657 & $-2.1525^{* *}$ & 0.1269 & 0.2745 & 0.7937 \\
\hline 10 & 0.0903 & 0.1571 & 1.0216 & 0.0601 & 0.5258 & 0.3265 & -0.1218 & 0.1527 & -0.8505 \\
\hline 11 & -0.1304 & 0.0268 & -1.5322 & -0.0155 & 0.5103 & -0.0967 & 0.0929 & 0.2456 & 0.4304 \\
\hline 12 & 0.03 & 0.0568 & 0.3362 & 0.2192 & 0.7295 & 1.3428 & 0.1887 & 0.4344 & 1.1575 \\
\hline 13 & -0.0238 & 0.033 & -0.2964 & 0.3969 & 1.1264 & $1.9521^{*}$ & 0.3427 & 0.7771 & $1.6957^{*}$ \\
\hline 14 & -0.1308 & -0.0978 & -1.5697 & 0.4195 & 1.5459 & $2.0805^{* *}$ & 0.0718 & 0.8489 & 0.4879 \\
\hline 15 & -0.1256 & -0.2234 & -1.3479 & 0.2204 & 1.7663 & 1.2012 & 0.027 & 0.8759 & 0.1626 \\
\hline 16 & -0.0463 & -0.2697 & -0.5951 & 0.1199 & 1.8862 & 0.7936 & -0.0117 & 0.8642 & -0.0747 \\
\hline 17 & 0.0364 & -0.2332 & 0.397 & 0.3745 & 2.2607 & $1.7670^{*}$ & -0.2708 & 0.5933 & -1.6556 \\
\hline 18 & -0.1538 & -0.3871 & $-2.0841^{* *}$ & 0.0729 & 2.3336 & 0.3062 & 0.0285 & 0.6218 & 0.1827 \\
\hline 19 & 0.0038 & -0.3833 & 0.0431 & -0.0817 & 2.2519 & -0.5216 & -0.1366 & 0.4852 & -0.8452 \\
\hline 20 & -0.1369 & -0.5202 & -1.5387 & -0.1112 & 2.1406 & -0.7577 & 0.2232 & 0.7084 & 1.2792 \\
\hline
\end{tabular}




\begin{tabular}{cccccccccc}
21 & 0.0559 & -0.4643 & 0.5931 & 0.0391 & 2.1798 & 0.2512 & -0.0878 & 0.6206 & -0.5441 \\
22 & 0.1484 & -0.3159 & $1.6493^{*}$ & -0.0884 & 2.0914 & -0.4386 & 0.0355 & 0.6561 & 0.2315 \\
23 & 0.1207 & -0.1952 & 1.3853 & 0.1657 & 2.2571 & 1.065 & 0.1925 & 0.8486 & 1.1994 \\
24 & -0.1602 & -0.3554 & $-1.9260^{*}$ & 0.0467 & 2.3038 & 0.276 & 0.0439 & 0.8925 & 0.2706 \\
25 & 0.1564 & -0.199 & $1.8562^{*}$ & 0.3712 & 2.675 & $1.8044^{*}$ & 0.2897 & 1.1822 & $1.6662^{*}$ \\
26 & 0.0822 & -0.1168 & 0.9916 & 0.4112 & 3.0862 & $1.9660^{*}$ & 0.1038 & 1.286 & 0.666 \\
27 & 0.0286 & -0.0882 & 0.3415 & -0.0909 & 2.9953 & -0.6062 & 0.205 & 1.491 & 1.4035 \\
28 & 0.0283 & -0.06 & 0.3038 & 0.0218 & 3.017 & 0.1471 & -0.1245 & 1.3665 & -0.8308 \\
29 & -0.1608 & -0.2207 & $-1.7764^{*}$ & -0.0992 & 2.9179 & -0.6295 & -0.1476 & 1.2189 & -0.7952 \\
30 & -0.1051 & -0.3259 & -1.2765 & -0.2191 & 2.6988 & -1.4471 & 0.1067 & 1.3256 & 0.6092 \\
\hline
\end{tabular}

Note: *** significant @ 1\%,** significant @ 5\% and *significant @ 10\% level

Source: Author's calculations

It is found from table 4 that large-cap sample dividend increase announcement average abnormal returns (AAR) are slightly negative on event day and statistically not significant. Abnormal returns are positive and not significant on -1 and -2 days after the event day. Before and after the event day, abnormal returns were either slightly positive or negative and observed significant returns five days after the event. Cumulative abnormal returns are negative throughout the window period. Returns are decreased till the event day, then slightly increased, but after the tenth day of the event, returns shown a negative trend again till the end of the window. From table 4, the large-cap sample dividend decrease announcement average abnormal returns (AAR) are negative on event day and statistically not significant. Abnormal returns are positive in most of the days before the event except the initial days of the window and significant in three days only. Abnormal returns are negative after the event, but after the second day of the event, returns are positive on most of the days, and also returns are significant on some days. Cumulative abnormal returns are positive throughout the window period except for the initial days of the window. Returns are increased till the event day and after the event day; also, returns shown a positive trend till the end of the window.

It can be said that large-cap sample dividend no change announcement average abnormal returns (AAR) are slightly positive on event day and statistically not significant. Abnormal returns are positive on most of the days before the event and not significant on most of the days. Abnormal returns are positive in most of the days after the event also and not significant in most of the days. Cumulative abnormal returns are positive in most of the days' window period except two days in the initial days before the event. Returns are increased till the event day and after the event day; also, returns shown an increasing trend till the end of the window. In the large-cap sample, dividend change announcement not observed a positive impact on stock prices like what we observed in the full sample, especially opposite results observed for dividend increase announcement.

\subsection{Mid-Caps}

Table 5. Mid-cap sample dividend change announcements average abnormal returns (AAR), cumulative average abnormal returns (CAAR), and AAR t values

\begin{tabular}{|c|c|c|c|c|c|c|c|c|c|}
\hline \multirow{2}{*}{ EW } & \multicolumn{3}{|c|}{ Dividend Increase $\mathrm{N}=300$} & \multicolumn{3}{|c|}{ Dividend Decrease $\mathrm{N}=102$} & \multicolumn{3}{|c|}{ Dividend No Change $\mathrm{N}=150$} \\
\hline & $\operatorname{AAR}(\%)$ & CAAR $(\%)$ & $\mathrm{t}$ Values & AAR $(\%)$ & CAAR $(\%)$ & $\mathrm{t}$ Values & $\operatorname{AAR}(\%)$ & CAAR (\%) & $\mathrm{t}$ Values \\
\hline-30 & 0.0016 & 0.0016 & 0.0133 & 0.0339 & 0.0339 & 0.1608 & 0.1441 & 0.1441 & 0.9578 \\
\hline-29 & 0.1374 & 0.1389 & 1.1755 & -0.3452 & -0.3113 & $-2.1568^{* *}$ & 0.0804 & 0.2246 & 0.4026 \\
\hline-28 & 0.274 & 0.413 & $2.2118^{* *}$ & -0.1533 & -0.4646 & -0.9494 & 0.0479 & 0.2725 & 0.3093 \\
\hline-27 & 0.111 & 0.5239 & 0.8464 & 0.5561 & 0.0914 & $2.3567^{* *}$ & -0.1501 & 0.1224 & -0.9701 \\
\hline-26 & 0.0258 & 0.5497 & 0.2413 & 0.1497 & 0.2411 & 0.6853 & 0.0673 & 0.1897 & 0.427 \\
\hline-25 & -0.1496 & 0.4001 & -1.6453 & 0.1695 & 0.4106 & 0.8598 & 0.124 & 0.3137 & 0.9036 \\
\hline-24 & 0.2968 & 0.6969 & $2.1369^{* *}$ & 0.0101 & 0.4207 & 0.0576 & -0.0606 & 0.2531 & -0.4511 \\
\hline-23 & -0.0796 & 0.6173 & -0.7368 & -0.1232 & 0.2975 & -0.7775 & 0.1756 & 0.4287 & 1.1126 \\
\hline-22 & 0.1044 & 0.7217 & 0.8556 & -0.2466 & 0.0509 & -1.3523 & -0.0937 & 0.335 & -0.6262 \\
\hline-21 & -0.0748 & 0.6469 & -0.6931 & 0.1498 & 0.2006 & 0.8287 & 0.2457 & 0.5807 & 1.4651 \\
\hline-20 & 0.2782 & 0.9251 & $2.1434^{* *}$ & -0.1248 & 0.0758 & -0.6712 & 0.1257 & 0.7064 & 0.9101 \\
\hline-19 & 0.0215 & 0.9466 & 0.1967 & 0.1054 & 0.1812 & 0.4067 & -0.0954 & 0.611 & -0.5453 \\
\hline-18 & -0.0012 & 0.9454 & -0.0123 & -0.2363 & -0.0551 & -1.1253 & 0.0359 & 0.647 & 0.2317 \\
\hline-17 & 0.1234 & 1.0688 & 1.0485 & 0.0948 & 0.0398 & 0.4591 & 0.1351 & 0.7821 & 0.7249 \\
\hline-16 & -0.2031 & 0.8657 & $-2.005^{* *}$ & -0.0096 & 0.0302 & -0.0422 & -0.1571 & 0.625 & -1.0227 \\
\hline-15 & 0.0516 & 0.9173 & 0.4748 & -0.2966 & -0.2665 & -1.8888 & 0.3211 & 0.9461 & $1.9654^{*}$ \\
\hline-14 & -0.0428 & 0.8744 & -0.38 & 0.0693 & -0.1972 & 0.3989 & 0.253 & 1.1991 & 0.8859 \\
\hline-13 & 0.0104 & 0.8849 & 0.0993 & 0.0901 & -0.1071 & 0.5166 & -0.2711 & 0.928 & $-1.9068^{*}$ \\
\hline-12 & 0.1209 & 1.0058 & 1.1564 & 0.1718 & 0.0648 & 0.9192 & -0.0009 & 0.9271 & -0.0052 \\
\hline-11 & -0.0175 & 0.9883 & -0.1595 & -0.1437 & -0.079 & -0.829 & 0.2243 & 1.1514 & 1.5035 \\
\hline
\end{tabular}




\begin{tabular}{|c|c|c|c|c|c|c|c|c|c|}
\hline-10 & -0.0414 & 0.9469 & -0.3733 & 0.0148 & -0.0641 & 0.0619 & -0.0704 & 1.081 & -0.4763 \\
\hline-9 & -0.2095 & 0.7374 & $-2.096^{* *}$ & -0.0117 & -0.0759 & -0.0638 & -0.0133 & 1.0677 & -0.0994 \\
\hline-8 & 0.1002 & 0.8376 & 0.8559 & -0.079 & -0.1549 & -0.5017 & -0.4425 & 0.6252 & $-3.046^{* * *}$ \\
\hline-7 & -0.0679 & 0.7696 & -0.6424 & -0.2138 & -0.3687 & -1.297 & 0.3397 & 0.9649 & 1.5931 \\
\hline-6 & -0.0487 & 0.7209 & -0.4772 & 0.3578 & -0.0109 & $1.6623^{*}$ & -0.1441 & 0.8207 & -0.8722 \\
\hline-5 & 0.0865 & 0.8074 & 0.8135 & 0.2447 & 0.2338 & 0.7776 & 0.3322 & 1.1529 & 1.5901 \\
\hline-4 & -0.1781 & 0.6293 & $-1.718^{*}$ & -0.0109 & 0.2229 & -0.0517 & 0.0244 & 1.1774 & 0.119 \\
\hline-3 & -0.1006 & 0.5287 & -0.9282 & 0.2257 & 0.4485 & 1.1037 & -0.0146 & 1.1628 & -0.0827 \\
\hline-2 & 0.0416 & 0.5704 & 0.3566 & 0.0456 & 0.4942 & 0.2462 & 0.187 & 1.3498 & 1.0342 \\
\hline-1 & 0.1896 & 0.76 & 1.3628 & -0.2433 & 0.2508 & -1.2766 & -0.0784 & 1.2714 & -0.5119 \\
\hline 0 & 0.4191 & 1.1791 & $2.0734^{* * *}$ & 0.0451 & 0.2959 & 0.2191 & -0.0257 & 1.2457 & -0.104 \\
\hline 1 & 0.2707 & 1.4498 & 1.3935 & -0.1619 & 0.134 & -0.5567 & -0.5479 & 0.6978 & $-2.0550^{* * *}$ \\
\hline 2 & 0.0416 & 1.4914 & 0.3218 & -0.1271 & 0.0069 & -0.4793 & -0.0267 & 0.6711 & -0.1438 \\
\hline 3 & -0.0763 & 1.4151 & -0.7581 & -0.3122 & -0.3053 & $-1.7290^{*}$ & 0.3103 & 0.9814 & $1.6624^{*}$ \\
\hline 4 & 0.1083 & 1.5234 & 0.8418 & -0.0129 & -0.3182 & -0.0584 & 0.0357 & 1.0171 & 0.1804 \\
\hline 5 & -0.0716 & 1.4518 & -0.5449 & -0.3875 & -0.7057 & -1.0576 & 0.1836 & 1.2007 & 1.1069 \\
\hline 6 & -0.0254 & 1.4263 & -0.2212 & 0.2656 & -0.4401 & 1.3556 & 0.0833 & 1.284 & 0.5128 \\
\hline 7 & 0.0586 & 1.4849 & 0.4867 & 0.3057 & -0.1344 & 1.4923 & 0.1504 & 1.4344 & 0.7978 \\
\hline 8 & -0.1572 & 1.3277 & -1.4513 & -0.1338 & -0.2682 & -0.5807 & -0.0859 & 1.3485 & -0.6254 \\
\hline 9 & 0.1378 & 1.4656 & 1.1951 & -0.5337 & -0.802 & $-2.7096^{* * * *}$ & 0.1411 & 1.4896 & 0.9123 \\
\hline 10 & 0.0006 & 1.4662 & 0.0054 & 0.0363 & -0.7657 & 0.1609 & -0.1501 & 1.3395 & -0.862 \\
\hline 11 & 0.095 & 1.5612 & 0.7552 & -0.4031 & -1.1688 & $-2.5998^{* *}$ & -0.0658 & 1.2736 & -0.4139 \\
\hline 12 & -0.0344 & 1.5268 & -0.3202 & 0.1512 & -1.0176 & 0.8654 & 0.1323 & 1.4059 & 0.9164 \\
\hline 13 & 0.044 & 1.5708 & 0.4105 & 0.0263 & -0.9913 & 0.1567 & 0.1655 & 1.5714 & 0.8553 \\
\hline 14 & -0.015 & 1.5558 & -0.1263 & 0.3667 & -0.6246 & 1.5674 & 0.1313 & 1.7027 & 0.6123 \\
\hline 15 & -0.0092 & 1.5466 & -0.0819 & 0.0566 & -0.568 & 0.2554 & -0.0562 & 1.6465 & -0.3589 \\
\hline 16 & 0.0432 & 1.5898 & 0.3564 & -0.0296 & -0.5975 & -0.1661 & 0.1209 & 1.7674 & 0.7454 \\
\hline 17 & -0.099 & 1.4908 & -0.9151 & -0.1178 & -0.7153 & -0.6953 & 0.1711 & 1.9384 & 1.1572 \\
\hline 18 & -0.1286 & 1.3622 & -1.05 & -0.1433 & -0.8587 & -0.7918 & -0.3 & 1.6385 & $-2.2314^{* * *}$ \\
\hline 19 & 0.0081 & 1.3703 & 0.0743 & 0.2294 & -0.6293 & 1.2589 & -0.0291 & 1.6093 & -0.1977 \\
\hline 20 & -0.0598 & 1.3106 & -0.5341 & -0.223 & -0.8523 & -1.1791 & -0.2554 & 1.3539 & $-2.0840^{* * *}$ \\
\hline 21 & 0.0765 & 1.3871 & 0.6431 & 0.0684 & -0.7839 & 0.423 & 0.094 & 1.4479 & 0.4726 \\
\hline 22 & -0.156 & 1.2311 & -1.3943 & 0.147 & -0.6369 & 0.7721 & 0.1566 & 1.6045 & 0.9876 \\
\hline 23 & -0.1172 & 1.114 & -1.174 & -0.3486 & -0.9854 & $-1.9640^{*}$ & 0.2163 & 1.8208 & 1.1488 \\
\hline 24 & -0.027 & 1.087 & -0.2568 & 0.1474 & -0.838 & 0.7832 & 0.0175 & 1.8383 & 0.126 \\
\hline 25 & 0.016 & 1.103 & 0.1568 & 0.3703 & -0.4677 & 1.6216 & 0.182 & 2.0203 & 1.1036 \\
\hline 26 & -0.0559 & 1.0471 & -0.4615 & 0.4305 & -0.0372 & $2.1748^{* * *}$ & -0.0227 & 1.9975 & -0.1535 \\
\hline 27 & 0.2111 & 1.2582 & $1.9093^{*}$ & 0.0498 & 0.0126 & 0.273 & -0.0284 & 1.9691 & -0.1901 \\
\hline 28 & 0.0346 & 1.2928 & 0.3158 & 0.2061 & 0.2186 & 0.9336 & 0.1417 & 2.1108 & 1.1416 \\
\hline 29 & -0.053 & 1.2398 & -0.4114 & 0.0335 & 0.2522 & 0.1633 & -0.2498 & 1.861 & -1.9134 \\
\hline 30 & 0.0456 & 1.2854 & 0.3376 & 0.4011 & 0.6533 & 1.6081 & -0.2035 & 1.6575 & -1.2153 \\
\hline
\end{tabular}

Note: *** significant @ 1\%,** significant @ 5\% and *significant @10\% level

Source: Author's calculations

It is observed from table 5 that mid-cap sample dividend increase announcement average abnormal returns (AAR) are positive on event day and statistically significant at 5 percent level. Abnormal returns are positive and not significant on -1 and -2 days before the event day and $+1,+2$ days after the event. It shows that investors are expecting positive signals from dividend increase stocks. But after event day, abnormal returns were either slightly positive or negative and not observed no significant returns in most of the days. Cumulative abnormal returns are positive throughout the window period, and returns are increased till the event day. From table 5, the mid-cap sample dividend decrease announcement average abnormal returns (AAR) are slightly positive on event day and statistically not significant. Abnormal returns are negative after the event, but after the 5th-day, returns are mostly positive. Abnormal returns are negative before the event, and also, returns are not significant on most of the days. Cumulative abnormal returns are negative on most of the days throughout the window period. It is also observed the more volatile CAR returns during the window period.

It can be said that mid-cap sample dividend no change announcement average abnormal returns (AAR) are slightly negative on event day and statistically insignificant. Abnormal returns are positive in most of the days before the event and significant in only three days. Abnormal returns are negative on -1 and -2 days after event day but significant only on -1 day. Abnormal returns are negative after the event, but after the second day of the event, returns are positive on most of the days, and also returns are significant in three days. Cumulative abnormal returns are positive in most of the days' window period; returns are increased till the event day and after the event day; also, returns shown an increasing trend till the end of the window. In the mid-cap sample, dividend change 
announcement observed a positive impact on stock prices like what we observed in the full sample, especially the same results observed for dividend increase announcement only.

\subsection{Small-Caps}

Table 6. Small-cap sample dividend change announcements average abnormal returns (AAR), cumulative average abnormal returns (CAAR), and AAR t values

\begin{tabular}{|c|c|c|c|c|c|c|c|c|c|}
\hline \multirow{2}{*}{ EW } & \multicolumn{3}{|c|}{ Dividend Increases $\mathrm{N}=523$} & \multicolumn{3}{|c|}{ Dividend Decreases $\mathrm{N}=178$} & \multicolumn{3}{|c|}{ Dividend No Change $N=373$} \\
\hline & $\operatorname{AAR}(\%)$ & CAAR $(\%)$ & $\mathrm{t}$ Values & $\operatorname{AAR}(\%)$ & CAAR $(\%)$ & $\mathrm{t}$ Values & $\operatorname{AAR}(\%)$ & CAAR $(\%)$ & t Values \\
\hline-30 & 0.110 & 0.11 & 1.0796 & 0.333 & 0.333 & $1.7942^{*}$ & 0.2084 & 0.2084 & 1.5679 \\
\hline-29 & -0.0212 & 0.0888 & -0.2205 & 0.1566 & 0.4897 & 1.1008 & -0.0718 & 0.1366 & -0.6094 \\
\hline-28 & 0.0252 & 0.114 & 0.231 & 0.3398 & 0.8295 & $1.9867^{* *}$ & 0.0028 & 0.1394 & 0.0258 \\
\hline-27 & 0.082 & 0.196 & 0.7906 & 0.3812 & 1.2107 & $2.0554^{* *}$ & -0.2047 & -0.0653 & $-1.896^{*}$ \\
\hline-26 & 0.0068 & 0.2028 & 0.0731 & 0.2477 & 1.4584 & 1.3727 & 0.1689 & 0.1036 & 1.3417 \\
\hline-25 & -0.0977 & 0.1051 & -0.9857 & 0.2323 & 1.6907 & 1.4642 & -0.154 & -0.0505 & -1.221 \\
\hline-24 & -0.123 & -0.0179 & -1.2809 & -0.0206 & 1.6701 & -0.1396 & -0.2653 & -0.3158 & -1.9978 \\
\hline-23 & -0.0594 & -0.0773 & -0.5732 & -0.1911 & 1.479 & -1.0271 & 0.1446 & -0.1713 & 1.1669 \\
\hline-22 & 0.1123 & 0.0349 & 1.146 & 0.2128 & 1.6918 & 1.0928 & 0.1435 & -0.0278 & 1.2764 \\
\hline-21 & 0.002 & 0.037 & 0.0216 & 0.2413 & 1.9331 & 1.3293 & 0.0184 & -0.0093 & 0.1421 \\
\hline-20 & -0.1326 & -0.0957 & -1.5255 & 0.0842 & 2.0174 & 0.4378 & -0.065 & -0.0744 & -0.5512 \\
\hline-19 & -0.0237 & -0.1193 & -0.2301 & 0.2742 & 2.2915 & 1.6492 & 0.0722 & -0.0021 & 0.6542 \\
\hline-18 & 0.1011 & -0.0183 & 0.9965 & -0.2306 & 2.0609 & -1.2958 & 0.1775 & 0.1754 & 1.2503 \\
\hline-17 & 0.064 & 0.0457 & 0.6616 & -0.0258 & 2.0351 & -0.1293 & 0.17 & 0.3454 & 1.3394 \\
\hline-16 & -0.1133 & -0.0676 & -1.154 & 0.1578 & 2.1929 & 0.9076 & -0.0725 & 0.2729 & -0.6052 \\
\hline-15 & -0.006 & -0.0735 & -0.0571 & -0.2394 & 1.9535 & -1.4228 & 0.0327 & 0.3056 & 0.278 \\
\hline-14 & 0.012 & -0.0615 & 0.1366 & -0.2932 & 1.6603 & $-1.7819^{*}$ & -0.0694 & 0.2362 & -0.5887 \\
\hline-13 & -0.0736 & -0.1351 & -0.6479 & -0.1138 & 1.5465 & -0.7686 & 0.0453 & 0.2815 & 0.4259 \\
\hline-12 & 0.0787 & -0.0564 & 0.7779 & -0.3019 & 1.2446 & $-1.8443^{*}$ & 0.3532 & 0.6348 & $2.758^{* * * *}$ \\
\hline-11 & -0.1051 & -0.1615 & -1.1425 & 0.1164 & 1.361 & 0.7386 & -0.1864 & 0.4484 & $-1.780^{*}$ \\
\hline-10 & -0.0034 & -0.1649 & -0.0355 & 0.441 & 1.802 & $2.0313^{* *}$ & 0.1941 & 0.6425 & 1.6197 \\
\hline-9 & 0.123 & -0.042 & 1.1939 & -0.1357 & 1.6662 & -0.8723 & 0.1005 & 0.743 & 0.8372 \\
\hline-8 & 0.0358 & -0.0062 & 0.3753 & 0.0096 & 1.6758 & 0.0515 & 0.2607 & 1.0037 & $1.8663^{*}$ \\
\hline-7 & 0.0136 & 0.0074 & 0.1269 & 0.5285 & 2.2043 & $2.4847^{* * *}$ & 0.1134 & 1.1171 & 0.9629 \\
\hline-6 & 0.0934 & 0.1009 & 0.9997 & -0.3295 & 1.8748 & $-1.9416^{*}$ & 0.1385 & 1.2555 & 1.1178 \\
\hline-5 & -0.0114 & 0.0894 & -0.1252 & 0.1336 & 2.0084 & 0.7886 & 0.172 & 1.4275 & 1.2492 \\
\hline-4 & 0.1501 & 0.2395 & 1.4139 & 0.1842 & 2.1926 & 1.1214 & 0.0223 & 1.4498 & 0.1564 \\
\hline-3 & 0.0819 & 0.3214 & 0.8382 & 0.2643 & 2.4569 & 1.5529 & 0.0439 & 1.4937 & 0.355 \\
\hline-2 & 0.3451 & 0.6665 & $3.5604^{* * * *}$ & -0.0892 & 2.3677 & -0.5231 & 0.3306 & 1.8243 & 1.5377 \\
\hline-1 & 0.3606 & 1.0272 & $3.3161^{* * *}$ & 0.0269 & 2.3947 & 0.1681 & 0.2273 & 2.0516 & $1.6651^{*}$ \\
\hline 0 & 0.6472 & 1.6743 & $3.580^{* * * *}$ & -0.2628 & 2.1318 & -0.9352 & 0.056 & 2.1077 & 0.3063 \\
\hline 1 & -0.0806 & 1.5937 & -0.4758 & -0.3249 & 1.807 & -1.1736 & -0.1634 & 1.9443 & -0.8362 \\
\hline 2 & -0.0396 & 1.5541 & -0.3471 & -0.0848 & 1.7221 & -0.4279 & -0.3077 & 1.6365 & $-2.545^{* *}$ \\
\hline 3 & 0.0739 & 1.628 & 0.6384 & 0.3345 & 2.0566 & $1.7889^{*}$ & 0.0858 & 1.7223 & 0.6976 \\
\hline 4 & -0.0639 & 1.5641 & -0.6355 & -0.1866 & 1.87 & -1.0544 & -0.0456 & 1.6767 & -0.3745 \\
\hline 5 & -0.1469 & 1.4172 & -1.3794 & 0.0487 & 1.9187 & 0.2642 & 0.1034 & 1.7801 & 0.8232 \\
\hline 6 & 0.0343 & 1.4516 & 0.3392 & -0.1118 & 1.8069 & -0.6132 & 0.0139 & 1.794 & 0.1218 \\
\hline 7 & 0.0327 & 1.4843 & 0.3089 & 0.0274 & 1.8343 & 0.1556 & 0.0802 & 1.8742 & 0.7099 \\
\hline 8 & -0.1598 & 1.3245 & $-1.6713^{*}$ & -0.1032 & 1.7311 & -0.5866 & -0.0729 & 1.8013 & -0.6146 \\
\hline 9 & -0.178 & 1.1465 & $-1.7955^{*}$ & 0.243 & 1.9741 & $1.6881^{*}$ & -0.0654 & 1.7358 & -0.5875 \\
\hline 10 & -0.226 & 0.9205 & $-2.3430^{* *}$ & -0.0862 & 1.8879 & -0.4936 & -0.0022 & 1.7336 & -0.0202 \\
\hline 11 & 0.011 & 0.9315 & 0.1204 & 0.4395 & 2.3274 & $1.7921^{*}$ & -0.0647 & 1.6689 & -0.4994 \\
\hline 12 & 0.1537 & 1.0852 & 1.5584 & 0.2581 & 2.5855 & 1.5466 & 0.1527 & 1.8216 & 1.1647 \\
\hline 13 & -0.1701 & 0.9151 & $-1.7289^{*}$ & -0.1138 & 2.4717 & -0.6491 & 0.0382 & 1.8598 & 0.255 \\
\hline 14 & 0.0852 & 1.0004 & 0.8096 & 0.1429 & 2.6145 & 0.9433 & 0.1161 & 1.9759 & 0.9055 \\
\hline 15 & 0.0078 & 1.0082 & 0.0796 & 0.1792 & 2.7937 & 1.1363 & 0.1007 & 2.0765 & 0.8222 \\
\hline 16 & -0.1177 & 0.8905 & -1.2781 & -0.2316 & 2.5621 & -1.4416 & 0.1016 & 2.1782 & 0.7512 \\
\hline 17 & -0.1646 & 0.7259 & -1.6336 & 0.0502 & 2.6123 & 0.3174 & 0.1042 & 2.2824 & 0.8913 \\
\hline 18 & -0.011 & 0.7149 & -0.1154 & 0.2084 & 2.8207 & 1.3238 & 0.0286 & 2.311 & 0.2216 \\
\hline 19 & -0.0936 & 0.6213 & -0.8786 & 0.0007 & 2.8214 & 0.0044 & 0.1185 & 2.4294 & 0.7715 \\
\hline 20 & -0.1542 & 0.4671 & $-1.8962^{*}$ & 0.2342 & 3.0557 & 1.1654 & -0.1155 & 2.3139 & -0.9191 \\
\hline 21 & 0.0819 & 0.549 & 0.828 & -0.4974 & 2.5583 & $-2.664^{* * *}$ & -0.1705 & 2.1434 & -1.4973 \\
\hline 22 & -0.0144 & 0.5346 & -0.1608 & -0.1806 & 2.3776 & -0.9333 & 0.0191 & 2.1626 & 0.1446 \\
\hline 23 & 0.0064 & 0.5409 & 0.0683 & -0.1366 & 2.241 & -0.8826 & -0.0022 & 2.1604 & -0.0211 \\
\hline 24 & 0.008 & 0.549 & 0.0806 & 0.1471 & 2.3881 & 0.9061 & 0.0664 & 2.2268 & 0.5503 \\
\hline 25 & -0.0025 & 0.5465 & -0.0265 & 0.0498 & 2.4379 & 0.2479 & 0.2307 & 2.4575 & 1.4787 \\
\hline 26 & -0.0929 & 0.4536 & -1.0104 & 0.1774 & 2.6153 & 0.9522 & -0.0301 & 2.4274 & -0.2431 \\
\hline 27 & -0.0677 & 0.3859 & -0.6208 & 0.0569 & 2.6722 & 0.4035 & -0.1103 & 2.3171 & -0.9685 \\
\hline
\end{tabular}




\begin{tabular}{cccccccccc}
28 & -0.0426 & 0.3433 & -0.4459 & 0.1999 & 2.8722 & 1.1767 & 0.087 & 2.4041 & 0.7284 \\
29 & 0.0198 & 0.3631 & 0.2292 & 0.1293 & 3.0015 & 0.7355 & -0.1221 & 2.282 & -1.008 \\
30 & 0.0617 & 0.4248 & 0.5943 & -0.0255 & 2.9759 & -0.1654 & 0.0932 & 2.3752 & 0.7937 \\
\hline
\end{tabular}

Note: *** significant @ 1\%,** significant @ 5\% and *significant @ 10\% level

Source: Author's calculations

It is observed from table 6 that small-cap sample dividend increase announcement average abnormal returns (AAR) are positive on event day and statistically significant at 1 percent level. Abnormal returns are positive and significant at a 1 percent level on -1 and -2 days before the event day. It shows that investors are expecting positive signals from dividend increase stocks. But after event day, abnormal returns were either slightly positive or negative and not observed no significant returns in most of the days. Cumulative abnormal returns fluctuated more before the event and were positive after the window period. It is also observed that cumulative returns have shown decreasing trends after the event. From table 6, the small-cap sample dividend decrease announcement average abnormal returns (AAR) are negative on event day and statistically not significant. Abnormal returns are positive in most of the days before the event and significant in four days. Abnormal returns are negative after the event, but after the third day of the event, returns are positive on most of the days, and also returns are significant on some days. Cumulative abnormal returns are positive throughout the window period; returns are increased until the event day. After the event day, returns also show an increasing trend until the end of the window.

It can be said that small-cap sample dividend no change announcement average abnormal returns (AAR) are slightly positive on event day and statistically not significant. Abnormal returns are positive on most days before the event, and returns are significant in seven days. Abnormal returns are negative on -1 and -2 days and significant on - 2 days after the event day. Abnormal returns are negative after the event, but after the third day of the event, returns are positive most of the days, and returns are not significant on most of the days. Cumulative abnormal returns are positive in most of the days' window period except initial days. Returns are increased until the event day and after the event day, returns shown an increasing trend until the end of the window.

\subsection{Dividend Change Announcements}

Table 7. Consolidated values of capitalization wise dividend change announcements on event day

\begin{tabular}{ccllcccc}
\hline \multirow{2}{*}{ S. No } & \multirow{2}{*}{ Capitalization } & $\begin{array}{l}\text { Dividend } \\
\text { Change }\end{array}$ & $\mathrm{N}$ & AAR $(\%)$ & \multirow{2}{*}{ CAAR $(\%)$} & t Value & $\mathrm{p}$ Value \\
& \multirow{3}{*}{ Full Sample } & Increases & 1205 & $0.36834^{* * * *}$ & 0.95309 & 3.53759 & 0.00042 \\
2 & Decreases & 403 & -0.14713 & 1.18984 & -0.88595 & 0.37617 \\
3 & & No Change & 645 & 0.06254 & 1.68769 & 0.48351 & 0.6289 \\
\hline 4 & \multirow{2}{*}{ Large Cap } & Increases & 382 & -0.05331 & -0.21188 & -0.36936 & 0.71206 \\
5 & & Decreases & 126 & -0.13474 & 0.56145 & -0.42776 & 0.66956 \\
6 & & No Change & 119 & 0.19434 & 0.91783 & 0.78555 & 0.4337 \\
\hline 7 & \multirow{3}{*}{ Mid-Cap } & Increases & 300 & 0.41914 & 1.17912 & 2.07338 & 0.03899 \\
8 & & Decreases & 102 & 0.04511 & 0.29595 & 0.21906 & 0.82705 \\
9 & & No Change & 150 & -0.02571 & 1.24568 & -0.10396 & 0.91734 \\
\hline 10 & \multirow{2}{*}{ Small Cap } & Increases & 523 & $0.64717^{* * *}$ & 1.67433 & 3.58002 & 0.00038 \\
11 & & Decreases & 178 & -0.26283 & 2.13183 & -0.93525 & 0.35093 \\
12 & & No Change & 373 & 0.05603 & 2.10767 & 0.30626 & 0.75958 \\
\hline
\end{tabular}

Note: *** significant @ 1\%,** significant @ 5\% and *significant @ 10\% level

Source: Author's calculations

It can be understood from Table 7 that abnormal return of dividend increase is positive on event day for the full sample, mid-cap, and small-cap and also significant but for large-cap abnormal returns are negative and also not significant. So, it means that the market reacts positively to dividend increases announcement, and it is similar to most of the researcher's results. Abnormal return of dividend decrease announcements is negative on event day for the full sample, large-cap and small-cap returns are not significant, but for mid-cap, returns are slightly positive. Abnormal return of dividend no change announcement is slightly positive on event day for the full sample, and small-cap and slightly negative for mid-cap or almost zero for all three classifications, but returns are positive for the large-cap. So, finally, it can be understood that large-cap stocks are reacting differently to dividend change announcements than the other three classifications. Cumulative average abnormal returns are positive on event day for all classifications except large-cap dividend increase announcements. In a small-cap sample, the dividend change announcement observed a positive impact on stock prices like what we observed in the full sample. 


\subsection{Market Capitalization Performance}

Table 8. Capitalization wise dividend change announcements performance on event day

\begin{tabular}{clllcccc}
\hline S. No & $\begin{array}{l}\text { Dividend } \\
\text { Change }\end{array}$ & Description & $\mathrm{N}$ & $\begin{array}{l}\text { Average } \\
\text { Return }\end{array}$ & Variance & $\begin{array}{l}\text { Standard } \\
\text { Deviation }\end{array}$ & $\begin{array}{c}\text { Co-efficient } \\
\text { of Variation }\end{array}$ \\
\hline 1 & \multirow{2}{*}{ Increases } & Large-cap & 382 & -0.05331 & 7.95839 & 2.82106 & -52.91506 \\
2 & Mid-cap & 300 & 0.41914 & 12.25981 & 3.5014 & 8.35374 \\
3 & & Small-cap & 523 & 0.64717 & 17.09118 & 4.13415 & 6.38801 \\
\hline 4 & \multirow{2}{*}{ Decreases } & Large-cap & 126 & -0.13474 & 12.5006 & 3.53562 & -26.24123 \\
5 & Mid-cap & 99 & 0.04511 & 4.19735 & 2.04874 & 45.42156 \\
6 & & Small-cap & 178 & -0.26283 & 14.05752 & 3.74934 & -14.26537 \\
\hline 7 & \multirow{2}{*}{ No Change } & Large-cap & 119 & 0.19434 & 7.28347 & 2.69879 & 13.88663 \\
8 & & Mid-cap & 150 & -0.02571 & 9.17558 & 3.02912 & -117.8085 \\
9 & & Small-cap & 373 & 0.05603 & 12.58351 & 3.54733 & 63.31489 \\
\hline
\end{tabular}

Note: *** significant @ 1\%,** significant @ 5\% and *significant @ 10\% level

Source: Author's calculations

It is found from table 8 that small-cap variances are higher than large-cap and mid-cap in all three dividend change announcements. Mid-cap dividend increases and no change announcement variance are higher than large-cap variance, but mid-cap dividend decrease variance is lesser than a large-cap variance. So, by and large-cap, small-cap variances are high, and large-cap variances are low, and results are similar to other researchers. The coefficient variance of small-cap dividend increase announcement is low, which means that small-cap performance is good for a given risk. Most coefficient variances are negative, so it is difficult to compare the return and risk using a coefficient variation.

\subsection{Market Capitalization Variance}

Table 9. Capitalization wise dividend change announcements variances $F$ values on event day

\begin{tabular}{cllcc}
\hline S. No & $\begin{array}{l}\text { Dividend } \\
\text { Change }\end{array}$ & Description & F Value & P Value \\
\hline 1 & & F Value (Small Cap \& Large Cap) & $2.14757^{* * *}$ & $3.66 \mathrm{E}-15$ \\
2 & \multirow{2}{*}{ Increases } & F Value (Small Cap \& Mid-Cap) & $1.39408^{* * * *}$ & 0.000741 \\
3 & & F Value (Mid-cap \& Large-cap) & $1.54049^{* * *}$ & $3.43 \mathrm{E}-05$ \\
\hline 4 & \multirow{2}{*}{ Decreases } & F Value (Small Cap \& Large Cap) & 1.12455 & 0.242037 \\
5 & & F Value (Small Cap \& Mid-Cap) & $3.34914^{* * *}$ & $1.76 \mathrm{E}-10$ \\
6 & & F Value (Large-cap \& Mid-cap) & $2.97821^{* * *}$ & $2.11 \mathrm{E}-08$ \\
\hline 7 & \multirow{2}{*}{ No Change } & F Value (Small Cap \& Large Cap) & $1.72768^{* * *}$ & 0.000266 \\
8 & & F Value (Small Cap \& Mid-Cap) & $1.37141^{* *}$ & 0.012746 \\
9 & & F Value (Mid-cap \& Large-cap) & $1.25978^{*}$ & 0.094462 \\
\hline
\end{tabular}

Note: *** significant @ 1\%,** significant @ 5\% and *significant @ 10\% level

Source: Author's calculations

Table 9 explains the different dividend change announcement capitalization variances in comparison to one other. All variances are not equal at a different level of significance for all three dividend change announcements, except small-cap and large-cap dividend decrease announcement variances. All three cap variances are not equal at a 1 percent level of significance in dividend increase announcements. In dividend decrease announcements, only small-cap \& mid-cap and mid-cap \& large cap variances are not equal at 1 percent level significance. In dividend, no change announcement variances are not equal at a different level of significance, small-cap \& large cap variances at 1 percent level, small-cap \& mid-cap variances at a 5 percent level mid-cap \& large cap at 10 percent level of significance.

\section{Conclusion}

It is concluded from research that the full sample dividend change announcement positively impacts stock prices on event day in India and supports the signaling hypothesis in India. The results are similar to the Aharony and Swary (1980), Litzenberger and Ramaswamy (1982), Dhillon and Johnson (1994), Below and Johnson (1996), Travlos, Trigeorgis, and Vafaes (2001), Brio (2004), Bapat (2005), Wang (2005), Dasilas (2007), Jais, Karim, Funaoka, and Abidin (2009), Gupta, Dogra, Vashisht, and Ghai (2012), Berdnikova and Rogova (2014). Small-cap sample dividend change announcements also positively impact the stock market as similar to full sample dividend change announcements. It is also said that the large-cap sample dividend decreases announcement and mid-cap 
dividend increases announcement have impacted the market in the same direction.

In large-cap sample dividend change announcements, not observed positive impact on the stock market for dividend increases and mid-cap sample dividend change announcements, for dividend decreases not observed positive impact on the stock market or the same direction of movement the stocks on the event day. These results are consistent with Lang and Litzenberger (1989), Benartzi, Michaely, and Thaler (1997), Conroy, Eades, and Harris (2000), Chen, Firth, and Gao (2002), Goergen, Renneboog, and Silva (2003), Blau, Fuller, and Ness (2009), Sharma and Pandey (2014), but they proved for broader samples, not for the large-cap or mid-cap sample. From the above results, we can say that the impact of dividend change announcement on stock prices changes with the market capitalization of stocks. It means that the signaling hypothesis is not similar for all stocks, and it will change depending on the company's size.

It is also from the research that small-cap performance and variance is different than the large-cap and mid-cap companies. It is proved that small-cap stocks' standard deviation will be high in all the classifications. Results are similar to Wong (1989), Bandara and Samarakoon (2002), Sehgal and Tripathi (2006), and Switzer (2010). It is concluded that dividends send signals to the market, and the market reacts positively to the dividend change announcements on event day, but sometimes results may vary with the size of the company. Small-cap companies' variances are higher than large-cap and mid-cap companies, and small-cap variances are not equal to other variances. Cumulative average abnormal returns for most of the observations increased till event day after that also maintained the same level for most of the observations. So, it is also said that a semi-strong form of hypothesis holds in the Indian stock market. Finally, it is concluded that the dividend signaling hypothesis and market capitalization or size effect anomaly exist in the Indian stock market.

\section{Limitations}

- The study is restricted to the period from 2007 to 2019 and S\&P BSE 500 Index firms only.

- The study has not considered the face value of stocks for the change of dividend action, and only announcement percentage is taken for the dividend change classification of stocks.

- Stock available in BSE cap indices on January 2020 is the base for the classification of samples into large, mid, and small caps.

\section{References}

Aharony, J., \& Swary, I. (1980). Quarterly Dividend and Earnings Announcements and Stockholders' Returns: An Empirical Analysis. The Journal of Finance, 35(1), 1-12. https://doi.org/10.1111/j.1540-6261.1980.tb03466.x

Allen, F., Bernardo, A. E., \& Welch, I. (2000). A Theory of Dividends Based on Tax Clienteles. Journal of Finance, 55(6), 2499-2536. https://doi.org/10.1111/0022-1082.00298

Amihud, Y., \& Li, K. (2006). The Declining Information Content of Dividend Announcements and the effects of Institutional Holdings. Journal of Financial and Quantitative Analysis, 41(3), 637-660. https://doi.org/10.1017/s0022109000002568

Asquith, P., \& Mullins, D. (1983). The Impact of Initiating Dividend Payments on Shareholders' Wealth. The Journal of Business, 56(1), 77-96. https://doi.org/10.1086/296187

Athari, A. (2013). Market Reaction to Dividend Announcement-An Event Study Analysis. In 1th International Conference on New Directions in Business, Management, Finance and Economics. Retrieved from https://www.researchgate.net/publication/305379239

Athari, S. A. (2020). The effects of institutional settings and risks on bank dividend policy in an emerging market: Evidence from Tobit model. International Journal of Finance \& Economics, 2020, 1-23.

Baker, H. K. (1998). Do Changes in Dividends Signal the Future or the Past? CFA Digest, 28(1), 45-47.

Below, S., \& Johnson, K. (1996). An analysis of shareholder reaction to dividend announcements in bull and bear markets. Journal of Financial and Strategic Decisions, 9(3), 15-26. Retrieved from https://studyfinance.com/jfsd/pdffiles/v9n3/below.pdf

Berdnikova, G., \&Rogova, E. (2013). The analysis of market reaction on dividend announcements of Russian companies. GSOM emerging Markets Conference: Business and Government Perspectives. Retrieved from https://ssrn.com/abstract=2511873

Bessler, W., \& Nohel, T. (2000). Asymmetric Information, Dividend Reductions, and Contagion Effects in Bank Stock Returns. Journal of Banking and Finance, 24(11), 1831-1848. 
https://doi.org/10.1016/S0378-4266(99)00097-7

Bhattacharya, S. (1979). The Bird in the Hand. The Bell Journal of Economics, 10(1), 259-270. https://doi.org/10.2307/3003330

Chavali, K., \& Nusratunnisa. (2013). Impact of Dividends on Share Price Performance of Companies in Indian Context. SDMIMD Journal of Management, 4(1), 4-9. https://doi.org/10.18311/sdmimd/2013/2681

Chen, D. H., Liu, H. H., \& Huang, C. T. (2009). The Announcement Effect of Cash Dividend Changes on Share Prices: An Empirical Analysis of China. Chinese Economy, 42(1), 62-85. https://doi.org/10.2753/CES1097-1475420103

Dasilas, A., \&Leventis, S. (2011). Stock Market Reaction to Dividend Announcements: Evidence from Greek Stock Market. International Review of Economics and Finance, 20(2), 302-311. https://doi.org/10.1016/j.iref.2010.06.003

Del Brio, E. (2004). Insider Trading Around Dividend Announcements: The Spanish Evidence.

Dhillon, U. S., \& Johnson, H. (1994). The Effect of Dividend Changes on Stock and Bond Prices. The Journal of Finance, 49(1), 281-289. https://doi.org/10.1111/j.1540-6261.1994.tb04430.x

Dissa Bandara, P. H., \&Samarakoon, L. P. (2002). Dividend Announcements, Firm Size and Dividend in the SriLankan Stock Market.pdf. Sri Lanka Journal of Management, 7(2), 228-245.

Elfakhani, S. (1998). The Expected Favourableness of Dividend Signals, the Direction of Dividend Change and the Signalling Role of Dividend Announcements. Applied Financial Economics, 8(3), 221-230. https://doi.org/10.1080/096031098332989

Fehrs, D., Benesh, G., \& Peterson, D. (1988). Evidence of a Relation Between Stock Price Reactions around Cash Dividend Changes and Yields. The Journal of Financial Research, 11(2), 111-123. https://doi.org/10.1111/j.1475-6803.1988.tb00073.x

Goergen, M., Renneboog, L. D. R., \& Correia da Silva, L. (2005). When do German Firms Change Their Dividends? SSRN Electronic Journal. https://doi.org/10.2139/ssrn.379103

Grullon, G., Michaely, R., Benartzi, S., \& Thaler, R. H. (2005). Dividend changes do not signal changes in future profitability. Journal of Business, 78(5), 1659-1682. https://doi.org/10.1086/431438

Gunalp, B., Kadioglu, E., \& Killc, S. (2011). The Announcement Effect of Cash Dividend on Share Prices and the Tax Clientele Effect: Evidence from Turkish Capital Markets. Euro Conference 2011: Crises and Recovery in Emerging Markets. https://doi.org/10.13140/RG.2.1.2980.4400

Gupta, S., Dogra, B., Vashisht, A. K., \& Ghai, S. (2012). Stock Price Reactions to Dividend Announcements. International Journal of Management, 2(2), 23-31.

Hussainey, K., Chijoke, O., \& Chijokemgbame, M. (2011). Dividend policy and share price volatility: UK evidence. Journal of Risk Finance, 12(1), 57-68. https://doi.org/10.1108/15265941111100076

John, K., \& Larry, H. P. L. (1991). Insider Trading around Dividend Announcements: Theory and Evidence. The Journal of Finance, 46(4), 1361-1389. https://doi.org/10.1111/j.1540-6261.1991.tb04621.x

Kalay, A. (1982). The Ex-Dividend Day Behaviour of Stock Prices: A Re-Examination of the Clientele Effect. The Journal of Finance, 37(4), 1059-1070. https://doi.org/10.1111/j.1540-6261.1982.tb03598.x

Kane, A., Lee, Y., \& Marcus, A. (1984). Earnings and Dividend Announcements: Is There a Corroboration Effect? The Journal of Finance, 39(4), 1091-1099. https://doi.org/10.1111/j.1540-6261.1984.tb03894.x

Kumar, S. J., \& Shankar Pandey, V. (2014). Dividend Signalling and Market Efficiency in Emerging Economy: A Study of Indian Stock Market. International Journal of Finance and Accounting Studies, 2(2), 8-18. https://doi.org/10.7575/aiac.ijfas.v.2n.2p.8

Lang, H. P., \& Litzenberger, R. H. (1989). Dividend Announcements Cash Flow Signalling. Journal of Financial Economics, 24, 181-191. https://doi.org/10.1016/0304-405X(89)90077-9

Litzenberger, R., \& Ramaswamy, K. (1982). The Effects of Dividends on Common Stock Prices Tax Effects or Information Effects? The Journal of Finance, 37(2), 429-443.

Lukose, J., \& Sapar, N. R. (2011). Dividend Changes, Profitability and Earnings - A Study of Indian Manufacturing Firms. SSRN Electronic Journal.

Marisetty, N. (2017). A Study on the Impact of Dividend on Stock Prices. International Journal of Management 
Studies, 4(1), 1-9. Retrieved from http://www.researchersworld.com/ijms

Marisetty, N., \& Madasu, P. (2021). Corporate Announcements and Market Efficiency: A Case on Indian Capital Market. International Journal of Business and Management, 16(8), 71. https://doi.org/10.5539/ijbm.v16n8p71

Marisetty, N., \& Suresh Babu, M. (2017). Corporate (Dividend) Actions and Impact on Stock Abnormal Returns: A Study on Indian Context, International Journal of Management and Social Sciences Research, 6(11), 30-35.

Marisetty, N., Suresh Babu, M., \& Rao, S. V. R. (2020). An Empirical Study on Expected Return Models with Reference to Bonus Issues and Stock Splits in Indian Share Market. International Journal of Management (IJM), 11(5), 1612-1630.

Mcnichols, M., \& Dravid, A. (1990). Stock Dividends, Stock Splits, and Signaling. The Journal of Finance, 45(3), 857-879. https://doi.org/10.1111/j.1540-6261.1990.tb05109.x

Miller, M., \& Modigliani, F. (1961). Dividend Policy, Growth, and the Valuation of Shares. The Journal of Business, 34(4), 411-433. Retrieved from https://www.jstor.org/stable/2351143

Ngoc, D. B., \& Cuong, N. C. (2016). Dividend Announcement and Ex-dividend Announcement Effects on Stocks Returns. International Journal of Economics and Finance, 8(7), 207-215. https://doi.org/10.5539/ijef.v8n7p207

Perepeczo, A. (2013). Market Reactions to Dividend Announcements in Public Companies - Empirical Evidence, Actual Problems of Economics, Scientific Economic Journal, 2(1). https://dx.doi.org/10.2139/ssrn.2548969

Pettit, R. (1972). Dividend Announcements, Security Performance, and Capital Market Efficiency. The Journal of Finance, 27(5), 993-1007. https://doi.org/10.1111/j.1540-6261.1972.tb03018.x

Ross, S. A. (1977). Determination of Financial Structure: The Incentive- Signalling Approach. Bell J Econ, 8(1), 23-40. https://doi.org/10.2307/3003485

Sant, R., \& Cowan, A. R. (1994). Do dividends signal earnings? The case of omitted dividends. Journal of Banking and Finance, 18(6), 1113-1133. https://doi.org/10.1016/0378-4266(94)00063-8

Schwert, G. W. W. (2005). Anomalies and Market Efficiency. SSRN Electronic Journal. https://doi.org/10.2139/ssrn.338080

Shahid, H., Xia, X., Mahmood, F., \& Usman, M. (2010). Announcement Effects of Seasoned Equity Offerings in China. International Journal of Economics and Finance, 2(3), 163-169. https://doi.org/10.5539/ijef.v2n3p163

Switzer, L. N. (2010). The behaviour of small cap vs. large cap stocks in recessions and recoveries: Empirical evidence for the United States and Canada. North American Journal of Economics and Finance, 21(3), 332-346.

Taleb, L. (2019). Dividend Policy, Signaling Theory: A Literature Review. SSRN Electronic Journal. https://dx.doi.org/10.2139/ssrn.3359144

Travlos, N., Trigeorgis, L., \& Vafeas, N. (2001). Share-holder Wealth Effects of Dividend Policy Changes in an Emerging Stock Market: The Case of Cyprus. Multinational Finance Journal, 5(2), 87-112. https://doi.org/10.17578/5-2-1

Vieira, E., \& Raposo, C. (2007). Signalling with Dividends? The Signalling Effects of Dividend Change Announcements: New Evidence from Europe. SSRN Electronic Journal. https://doi.org/10.2139/ssrn.955768

Wang, Y. (2005). The Effect of Dividend Initiations on Stock Returns: A Propensity Score Matching Approach, 15.

\section{Copyrights}

Copyright for this article is retained by the author(s), with first publication rights granted to the journal.

This is an open-access article distributed under the terms and conditions of the Creative Commons Attribution license (http://creativecommons.org/licenses/by/4.0/). 